\title{
ANALISIS PENGARUH STRUKTUR MODAL, PROFITABILITAS, DAN UKURAN PERUSAHAAN TERHADAP NILAI PERUSAHAAN MANUFAKTUR SEKTOR INDUSTRI MAKANAN DAN MINUMAN TAHUN 2013-2017
}

\author{
Jasmine Putri Dewi ${ }^{1)}$ \\ Program Studi Akuntansi Fakultas Ekonomi \\ Universitas Krisnadwipayana \\ Email : putrijasmine18@yahoo.com \\ Esti Damayanti ${ }^{2)}$ \\ Program Studi Akuntansi Fakultas Ekonomi \\ Universitas Krisnadwipayana \\ Email : estidamayanti1678@gmail.com
}

\begin{abstract}
This study aims to analyze the effect of Capital Structure, Profitability and Company Size on the Value of Manufacturing Companies in the Food and Beverage Industry Sector in Indonesia. This research was conducted on annual data of manufacturing companies in the food and beverage industry in the form of DER, ROA and Ln data for the period 2013 - 2017. The results of this study indicate that partially the capital structure has a positive and significant effect on the value of manufacturing companies listed on the Stock Exchange, profitability has a significant effect on the value of manufacturing companies listed on the IDX, the size of the company has a significant effect on firm value. While simultaneously the capital structure, profitability and size of the company significantly influence the value of the company.
\end{abstract}

Keywords : Capital Structure, Profitability, Company Size, Company Value

\section{PENDAHULUAN}

Nilai perusahaan merupakan hal yang cukup penting karena mencerminkan kinerja perusahaan yang dapat mempengaruhi persepsi investor terhadap perusahaan.

Menurut Sulasmiyati, et.al (2016) nilai perusahaan akan tercermin dari harga saham di pasar saham. Harga saham di pasar modal terbentuk berdasarkan kesepakatan antara permintaan dan penawaran investor, sehingga harga saham merupakan fair price yang dapat dijadikan sebagai proksi nilai perusahaan. Nilai perusahaan yang tinggi juga menjadi keinginan setiap pemilik perusahaan. Karena nilai perusahaan yang tinggi, mengindikasikan kemakmuran pemegang sahamnya juga tinggi. Nilai perusahaan yang meningkat akan mempengaruhi nilai pemegang saham, apabila peningkatan ditandai dengan pengembalian investasi yang tinggi kepada pemegang saham.

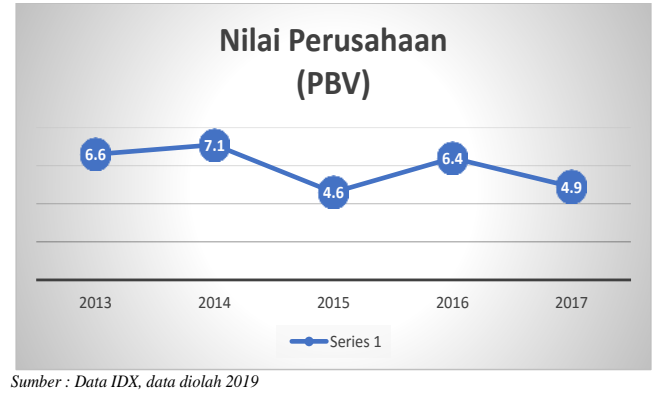

Gambar 1. Nilai Perusahaan Manufaktur Sektor Industri Tahun 2013 - 2017

Berdasarkan data grafik di atas, dapat dilihat bahwa rata-rata nilai perusahaan manufaktur industri makanan dan minuman yang terdaftar di BEI pada tahun 2013-2017 yang diukur dengan Price to Book Value (PBV) mengalami fluktuasi. Nilai perusahaan pada tahun 2014 dan 2016 mengalami peningkatan, akan tetapi pada tahun 2015 dan 2017 nilai perusahaan manufaktur indsutri makanan dan minuman mengalami penurunan yang cukup signifikan. Menurut (Alfredo 2011) ada beberapa faktor yang 
mempengaruhi nilai perusahaan yaitu keputusan pendanaan, kebijakan dividen, keputusan investasi, struktur modal, pertumbuhan perusahaan, ukuran perusahaan, dan profitabilitas. Beberapa faktor tersebut memiliki hubungan dan pengaruh terhadap nilai perusahaan yang tidak konsisten.

Ukuran perusahaan menunjukkan aktiva perusahaan yang dimiliki perusahaan. Semakin besar ukuran perusahaan maka semakin besar juga aktiva yang bisa dijadikan jaminan untuk mendapatkan hutang sehingga hutang akan meningkat Wijaya, et.al (2013). Ukuran perusahaan dinilai dari total aset yang dimiliki suatu perusahaan untuk kegiatan operasinya, semakin besar perusahaan tersebut maka semakin besar pula dana yang dibutuhkan untuk kegiatan operasional perusahaan. Ukuran perusahaan juga bias dijadikan sebagai proksi atas tingkat ketidak pastian saham. Perusahaan dengan skala besar cenderung lebih dikenal oleh masyarakat sehingga informasi mengenai prospek perusahaan yang berskala besar cendrung lebih mudah diperoleh investor daripada perusahaan yang berskala kecil.

Berdasarkan latar belakang di atas, maka permasalahan yang dapat dirumuskan dalam penelitian ini adalah apakah secara parsial struktur modal berpengaruh terhadap nilai perusahaan?Apakah secara parsial profitabilitas berpengaruh terhadap nilai perusahaan ?Apakah secara parsial ukuran perusahaan berpengaruh terhadap nilai perusahaan ?Lalu apakah secara simultan struktur modal, profitabilitas dan ukuran perusahaan berpengaruh terhadap nilai perusahaan manufaktur sektor industri makanan dan minuman yang terdaftar di Bursa Efek Indonesia periode tahun 2013-2017?

\section{Tinjauan Pustaka}

\section{Nilai Perusahaan}

Sunyoto (2015 : 24) menyebutkan bahwa yang dimaksud dengan nilai perusahaan adalah nilai perusahaan yaitu merupakan harga yang dibayar oleh calon pembeli apabila perusahaan tersebut dijual.

Rasio yang digunakan untuk mengukur nilai perusahaan salah satu diantaranya menggunakan Price to Book Value (PBV).
Price to book value (PBV) adalah rasio valuasi investasi yang sering digunakan untuk membandingkan nilai pasar saham perusahaan dengan nilai bukunya. Rasio ini menunjukan seberapa banyak pemegang saham yang membiayai aset bersih perusahaan. Price to book value juga merupakan salah satu indikator untuk melihat apakah suatu saham mahal atau tidak.

Struktur Modal

Struktur modal merupakan pendanaan ekuitas dan utang dalam suatu perusahaan. Struktur modal menentukan penggunaan utang yang dilakukan oleh manajer keuangan untuk mendanai kegiatan perusahaan tersebut. Selain itu struktur modal juga masalah yang penting bagi setiap perusahaan, karena baik buruknya struktur modal akan berpengaruh terhadap posisi financial perusahaan. Rasio yang dapat digunakan untuk mengukur struktur modal salah satunya adalah

Rasio Total Utang Terhadap Modal (Total Debt to Equity Ratio/ DER). Rasio ini digunakan untuk mengukur perimbangan antara kewajiban yang dimiliki perusahaan dengan modal sendiri. Rasio ini juga dapat berarti sebagai kemampuan perusahaan dalam memenuhi kewajiban membayar utangnya dengan jaminan modal sendiri. Perusahaan dengan total kewajiban yang lebih besar dibanding equity yang dimiliki perusahaan menunjukan tingkat resiko yang besar pada perusahaan tersebut. Semakin besar hutang akan meningkatkan biaya bunga dan menurunkan nilai perusahaan Brigham dan Houston (2015).

Struktur modal menentukan penggunaan utang yang dilakukan oleh manajer keuangan untuk mendanai kegiatan perusahaan. Struktur modal merupakan perimbangan jumlah utang jangka pendek yang bersifat permanen, utang jangka panjang, saham preferen, dan saham biasa. Keputusan pemilihan sumber dana, baik yang berasal dari modal sendiri maupun yang berasal dari modal asing dalam bentuk utang, kedua dana ini merupakan dana eksternal yang dapat mempengaruhi nilai perusahaan.

Profitabilitas

Profitabilitas merupakan kemampuan perusahaan untuk menghsilkan laba selama periode tertentu. Profitabilitas suatu 
perusahaan dapat dinilai melalui berbagai cara tergantung pada laba perusahaan dan aset atau modal yang akan diperbandingkan satu dengan lainnya.

Salah satu rasio yang dapat digunakan adalah Return on Asset Ratio(ROA). Tingkat pengembalian aset merupakan rasio profitabilitas untuk menilai persentase keuntungan (laba) yang diperoleh perusahaan terkait sumber daya atau total asset sehingga efisiensi suatu perusahaan dalam mengelola asetnya bisa terlihat dari persentase rasio ini.

Dengan menggunakan perhitungan rasio ROA kita dapat mengetahui apakah perusahaan telah efisien dalam memanfaatkan aktivanya dalam kegiatan operasional perusahaan. Perusahaan dengan nilai ROA yang bagus menunjukan bahwa perusahaan berada dalam kondisi kinerja yang baik, dengan kondisi kinerja yang baik maka perusahaan akan mendapatkan kepercayaan publik yang mengarah pada kegiatan pemodalan usaha sebagai kekuatan perusahaan dalam jangka panjang perusahaan.

Menurut Kasmir (2010:196) profitabilitas merupakan faktor yang dapat mempengaruhi nilai perusahaan. Profitabilitas adalah kemampuan suatu perusahaan memperoleh laba selama periode tertentu. Laba yang diperoleh perusahaan berasal dari penjualan, total aktiva maupun modal sendiri. Jika profitabilitas perusahaan baik, para investor dan kreditur bisa melihat sejauh mana perusahaan mampu menghasilkan laba dari penjualan dan investasi perusahaan. Selain itu profitabilitas yang tinggi menunjukkan prospek perusahaan yang bagus sehingga investor akan merespon positif dan harga saham meningkat.

Ukuran Perusahaan

Ukuran perusahaan menggambarkan besar kecilnya suatu perusahaan yang dapat dinyatakan dengan total aktiva. Dalam skala usaha terdapat berbagai macam ukuran perusahaan yang berbeda. Apapun ukuran perusahaannya tujuan yang ingin dicapai yaitu untuk menghasilkan laba bagi pemiliknya.

Variabel ukuran perusahaan diukur dengan Logaritma Natural (Ln) dari total aset dan total penjualan. Hal ini karena besarnya total aset dan total penjualan masing-masing perusahaan berbeda bahkan mempunyai selisih yang besar, sehingga dapat menyebabkan nilai yang ekstrim. Untuk menghindari adanya data yang tidak normal maka data total aset dan total penjualan perlu di logaritma natural kan.

Ukuran perusahaan menunjukkan aktiva perusahaan yang dimiliki perusahaan. Semakin besar ukuran perusahaan maka semakin besar juga aktiva yang bisa dijadikan jaminan untuk mendapatkan hutang sehingga hutang akan meningkat Wijaya, et.al (2013). Ukuran perusahaan dinilai dari total aset yang dimiliki suatu perusahaan untuk kegiatan operasinya, semakin besar perusahaan tersebut maka semakin besar pula dana yang dibutuhkan untuk kegiatan operasional perusahaan. Ukuran perusahaan juga bias dijadikan sebagai proksi atas tingkat ketidak pastian saham. Perusahaan dengan skala besar cenderung lebih dikenal oleh masyarakat sehingga informasi mengenai prospek perusahaan yang berskala besar cendrung lebih mudah diperoleh investor daripada perusahaan yang berskala kecil.

Tujuan penelitian ini adalah untuk membuktikan secara empiris tentang pengaruh struktur modal, profitabilitas, dan ukuran perusahaan terhadap nilai perusahaan pada perusahaan manufaktur sektor industri makanan dan minuman yang list di Bursa Efek Indonesia selama periode 2013-2017.

\section{METODE PENELITIAN \\ Variabel dan Pengukurannya}

Variabel yang digunakan dalam penelitian ini adalah variabel dependen yaitu nilai perusahaan dan variabel independen yaitu struktur modal, profitabilitas dan ukuran perusahaan.

\section{Populasi dan Sampel Penelitian}

Data yang digunakan dalam penelitian ini berupa laporan keuangan perusahaan manufaktur yang terdaftar di Bursa Efek Indonesia tahun 2013 - 2017. Teknik pengambilan sampel pada penelitian ini menggunakan purposive sampling.Teknik purposive sampling yang memenuhi kriteriakriteria sebagai berikut:

1. Perusahaan manufaktur dalam satu sub sektor industri yaitu makanan dan minuman yang terdaftar di Bursa Efek Indonesia pada tahun 2013-2017. 
2. Menerbitkan dan mempublikasikan laporan tahunan dan laporan keuangan audited selama tahun 2013-2017.

3. Menerbitkan laporan keuangan yang berakhir pada tanggal 31 Desember dan menggunakan mata uang rupiah.

4. Memiliki data yang lengkap dan sesuai dengan variabel yang diteliti.

\section{Teknik Analisis Data}

Teknik analisis data yang digunakan dalam penelitian ini yaitu analisis statistik deskriptif, uji asumsi klasik yang terdiri dari uji normalitas, uji multikolonieritas, uji autokorelasi, uji heteroskedastisitas. Pengujian hipotesis dilakukan dengan dua cara, menggunakan uji fisher (uji F) untuk melihat secara simultan semua variabel independen terhadap variabel dependen. Sedangkan uji $t$ untuk melihat secara parsial semua variabel independen terhadap variabel dependen. Koefisien Determinasi $\left(\mathrm{R}^{2}\right)$ mengukur seberapa jauh kemampuan model dalam menerangkan variasi variabel dependen.

\section{HASIL DAN PEMBAHASAN}

\section{Hasil Penelitian}

Hasil analisi uji statistik deskriptif dapat dilihat pada tabel 1 berikut:

Tabel 1. Statistik Deskriptif

\begin{tabular}{lrrrrrr}
\hline \multicolumn{6}{c}{ Descriptive Statistics } \\
\hline & $N$ & Minimum & Maximum & Mean & Std. Deviation \\
\cline { 2 - 7 } & Statistic & Statistic & Statistic & Statistic & Statistic \\
\hline DER & 65 & .02 & 45.10 & 3.665 & 10.19607 \\
\hline ROA & 65 & .11 & .97 & .4040 & .13696 \\
\hline LN & 65 & 12.62 & 18.34 & 14.992 & 1.46624 \\
\hline PBV & 65 & 3.86 & 4.25 & 4.0652 & .10011 \\
\hline Valid N (listwise) & 65 & & & & \\
\hline Sunber : output SPSS olahan penulis, 2019 & & &
\end{tabular}

Tabel 1 diatas menggambarkan bahwa jumlah data pengamatan yang digunakan dalam penelitian ini pada perusahaan manufaktur sektor industri makanan dan minuman yang terdaftar di Bursa Efek Indonesia sebanyak 65 sampel data (13 perusahaan selama 5 tahun), dapat dijelaskan bahwa :

1. Variabel struktur modal yang diukur dengan debt to equity ratio (DER) memiliki nilai terendah 0,02 dan nilai maksimum
45,10. Hal ini menunjukan bahwa perusahaan manufaktur dalam penelitian ini memiliki nilai hutang tertinggi sebesar 45,10 dari nilai ekuitasnya. Struktur modal yang besar dapat disebabkan karena meningkatnya hutang perusahaan dan menurunnya jumlah saham yang beredar. Nilai rata - rata sebesar 3,665 dan nilai standar deviasi 10,197. Nilai standar deviasi yang lebih besar dari nilai rata rata menunjukan bahwa debt to equity ratio perusahaan yang menjadi sampel dalam penelitian ini sangat bervariasi.

2. Variabel profitabilitas yang diukur dengan return on asset (ROA) memiliki nilai ratarata sebesar 0,404 dengan standar deviasi 0,136, hal ini menggambarkan bahwa perusahaan sampel rata-rata mampu menghasilkan keuntungan sebesar 0,404 dari total modalnya. Standar deviasi yang lebih kecil dari rata-rata menunjukan bahwa variasi data variabel profitabilitas kecil. Nilai maksimum variabel ROA sebesar 0,97 hal ini menunjukan bahwa perusahaan manufaktur dalam penelitian ini dapat menghasilkan laba setelah pajak sebesar Rp. 0,97 dari setiap Rp. 1 pendapatan. Nilai profitabilitas yang tinggi dikarenakan perusahaan dapat menghasilkan pendapatan yang tinggi dengan beban yang rendah, sedangkan nilai minimum ROA sebesar 0,11.

3. Variabel ukuran perusahaan yang diukur dengan logaritma natural (LN) memiliki nilai minimum sebesar 12,62 dan memiliki nilai maksimum sebesar 18,34 . Sedangkan nilai rata - rata 14,992 dan nilai standar deviasi 1,46624 artinya selama periode penelitian ukuran penyebaran dari variabel total aset sebesar 1,46624 miliar rupiah.

4. Variabel nilai perusahaan yang diukur dengan price to book value (PBV) memiliki nilai minimum sebesar 3,86 dan nilai maksimum 4,25. Rata rata PBV yang dimiliki 13 perusahaan sebesar 4,065 dan nilai standar deviasi PBV sebesar 0,10011, apabila nilai standar deviasi dibawah rata rata menunjukan bahwa variasi data variabel PBV rendah. 
Uji normalitas dalam penelitian ini menggunakan uji normalitas dengan menggunakan grafik normal.

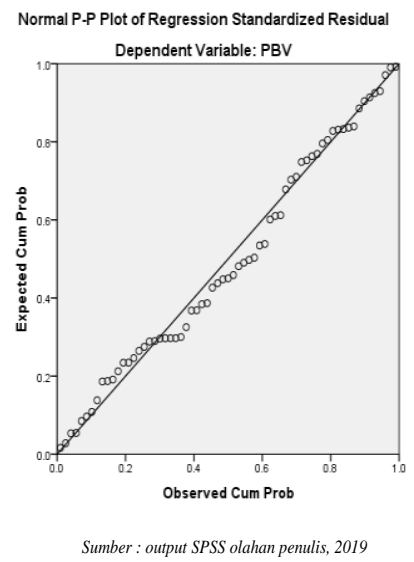

\section{Gambar 2. Grafik Normal P-P Plot}

Jika dilihat pada gambar P-P plot terlihat titik - titik mengikuti dan mendekati sumbu atau garis diagonalnya, sehingga dapat dinyatakan bahwa data berdistribusi normal.

Tabel 2. Uji Multikolinearitas

\begin{tabular}{|c|c|}
\hline \multicolumn{2}{|c|}{ Collinearity Statisitics } \\
\hline Tolerance & VIF \\
\hline .633 & 1.581 \\
\hline .983 & 1.017 \\
\hline .630 & 1.588 \\
\hline
\end{tabular}

Hal ini menunjukan bahwa model regresi dalam penelitian ini tidak terdapat masalah multikolinearitas.

Tabel 3. Uji Autokorelasi

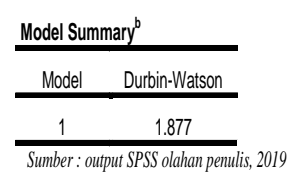

Dari penelitian yang dilakukan didapat nilai Durbin Watson 1.877. hal ini menunjukan nilai DW lebih besar dari batas atas (du) 1.696 dan nilai DW kurang dari 4 - 1696 sebesar 2.304, maka dapat dinyatakan dalam penelitian ini model regresi tidak terdapat autokorelasi positif atau negatif.

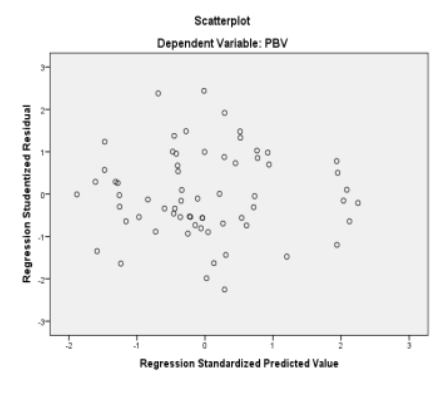

Sumber : output SPSS olahan penulis, 2019

Gambar 3. Uji Heteroskedastisitas

Berdasarkan gambar grafik scatterplot diatas, dapat dilihat bahwa pola titik pada grafik menyebar secara acak dibawah maupun diatas angka 0 dan tidak membentuk pola tertentu, maka bisa disimpulkan model regresi tersebut bebas heterokedastisitas.

Tabel 4. Model Regresi

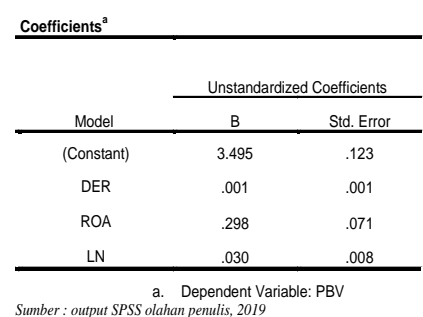


Berdasarkan tabel 4 diatas, data dalam penelitian ini dapat disusun dengan persamaan matematis sebagai berikut :

\section{$Y=3.495+0.001 X 1+0.298 X 2+0.030 X 3$}

Hasil dari pengujian Koefisien Determinasi dijelaskan bahwa nilai $R^{2}=0,438$ yaitu artinya adalah 43,8 persen PBV dipengaruhi oleh variabel DER, ROA dan LN, sedangkan sisanya 56,2 persen dipengaruhi oleh variabel lain yang tidak diteliti.

Dengan menggunakan tingkat signifikan 0,05 , df $1=$ jumlah variabel $-1=3$ dan df $2=$ (n-k-1) atau 65-3-1= 61, maka diperoleh $\mathrm{F}$ tabel sebesar 2,75. Berdasarkan tabel diatas F hitung > F tabel $(15,870>2,75)$ maka Ho ditolak, artinya yaitu struktur modal, profitabilitas dan ukuran perusahaan secara simultan berpengaruh terhadap nilai perusahaan dengan signifikansi sebesar 0,000 $<0,05$.

Tabel 5. Uji T Parsial DER

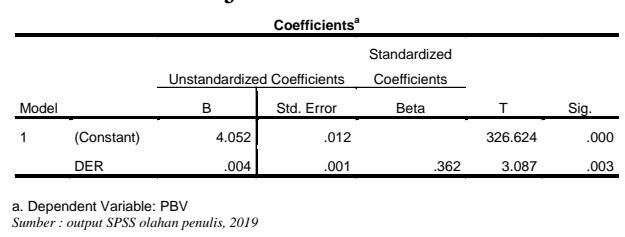

Tabel 6 .Uji T Parsial ROA

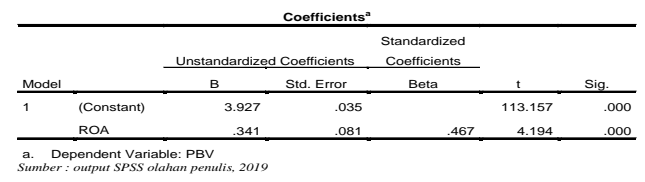

Tabel 7. Uji T Parsial Ln

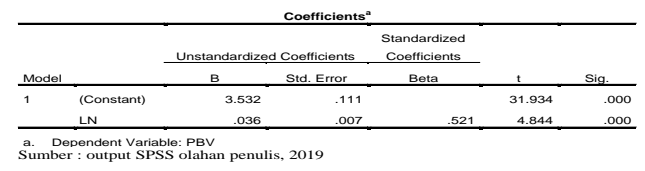

Berdasarkan tabel diatas, dapat disimpulkan bahwa hasil uji t bahwa:

1. Variabel struktur modal memiliki nilai $\mathrm{t}$ hitung > $\mathrm{t}$ tabel dimana 3,087>1,99 dengan tingkat signifikansi 0,003 lebih kecil dari 0,05 sehingga dapat dinyatakan bahwa struktur modal berpengaruh secara signifikan terhadap variabel nilai perusahaan.

2. Variabel profitabilitas memiliki nilai $t$ hitung > $\mathrm{t}$ tabel dimana 4,194>1,99 dengan tingkat signifikansi 0,000 , sehingga dapat dinyatakan bahwa profitabilitas berpengaruh secara signifikan terhadap variabel nilai perusahaan.

3. Variabel ukuran perusahaan juga memiliki nilai t hitung $<\mathrm{t}$ tabel dimana 4,844 $<1,99$ dengan tingkat signifikansi 0,000 , sehingga dapat dinyatakan bahwa ukuran perusahaan berpengaruh signifikan terhadap variabel nilai perusahaan.

\section{Pembahasan}

Hasil penelitian yang dilakukan menunjukan bahwa variabel struktur modal yang diukur dengan debt to equity ratio (DER) berpengaruh terhadap nilai perusahaan. Hal ini ditunjukan dari hasil uji statistik $t$ yang memperoleh $\mathrm{t}$ hitung sebesar 3,087 dan signifikansi sebesar 0,003 . Nilai t hitung lebih besar dari nilai t tabel 3,087 > 1,99, hal ini dapat dilihat dari modal yang digunakan oleh perusahaan tersebut terdiri dari modal asing dan modal sendiri. Apabila perusahaan lebih banyak mendapatkan modal dari luar untuk menjalankan kegiatan operasionalnya, hal ini menggambarkan hutang dan suku bunga yang tinggi. Apabila pajak suatu perusahaan rendah, maka akan meningkatkan laba atau keuntungan perusahaan. Jika laba meningkat maka akan meningkatkan pula harga saham yang dapat mendorong nilai perusahaan. Jadi dapat disimpulkan bahwa struktur modal berpengaruh terhadap nilai perusahaan. Hasil ini sesuai dengan penelitian yang dilakukan oleh Fery Anggriawan (2016) yang meneliti struktur modal terhadap nilai perusahaan pada perusahaan manufaktur sektor makanan dan minuman, menyatakan bahwa struktur modal berpengaruh terhadap nilai perusahaan. 
Variabel profitabiltas yang diukur dengan return on asset (ROA) berpengaruh terhadap nilai perusahaan. Hal ini ditunjukan dari hasil uji statistik $\mathrm{t}$ yang memperoleh $\mathrm{t}$ hitung sebesar 4,194 dan signifikansi sebesar 0,000. Nilai t hitung lebih besar dari nilai t tabel $4,194>1,99$. Jadi dapat disimpulkan bahwa profitabilitas berpengaruh terhadap nilai perusahaan, hal ini menunjukan bahwa semakin besar profitabilitas suatu perusahaan maka semakin besar pula nilai suatu perusahaan. Apabila profitabilitas suatu perusahaan semakin besar, maka kinerja perusahaan tersebut semakin produktif. Sehingga dapat meningkatkan kepercayaan investor untuk menanamkan modalnya dan nilai perusahaan akan semakin membaik dengan pendapatan laba dari penanaman modal para investor.

Selain itu profitabilitas juga bisa mengukur kemampuan manajemen suatu perusahaan dalam menjalankan kegiatan operasionalnya, yaitu dengan meminimalkan beban perusahaan dan memaksimalkan laba perusahaan sehingga bisa meningkatkan nilai perusahaan (Dewanto et all, 2017). Profitabilitas yang tinggi menunjukan bahwa perusahaan berada dalam kondisi yang baik dan menguntungkan. Hal ini bisa menjadi daya Tarik investor untuk memiliki saham perusahaan tersebut, permintaan saham yang tinggi akan membuat nilai saham lebih besar daripada nilai yang tercatat pada neraca perusahaan.

Variabel ukuran perusahaan yang diukur dengan logaritma natural (LN) berpengaruh terhadap nilai perusahaan. Hal ini ditunjukan dari hasil uji statistik $\mathrm{t}$ yang memperoleh $\mathrm{t}$ hitung sebesar 4,844 dan signifikansi sebesar 0,000 . Nilai $t$ hitung lebih besar dari nilai t tabel 4,844 > 1,99. Dapat disimpulkan bahwa ukuran perusahaan berpengaruh terhadap nilai perusahaan, hal ini menunujukan bahwa semakin besar ukuran perusahaan maka akan semakin mudah suatu perusahaan dalam memperoleh sumber pendanaan. Sehingga perusahaan dapat memiliki sumber dana yang banyak untuk kegiatan operasional perusahaan, jika ukuran suatu perusahaan semakin besar maka akan semakin banyak investor yang menaruh investasinya diperusahaan tersebut dan dapat meningkatkan nilai perusahaan. Hal tersebut menunjukan bahwa peningkatan ukuran perusahaan akan diikutin dengan peningkatan maupun penurunan nilai perusahaan.

Dari hasil pengujian secara simultan, menunjukan bahwa nilai $\mathrm{F}$ hitung $>\mathrm{F}$ tabel yaitu $15,870>2,75$ dengan tingkat signifikansi 0,000. Hal ini menjelaskan bahwa Ho ditolak artinya struktur modal, profitabilitas dan ukuran perusahaan secara simultan berpengaruh signifikan terhadap nilai perusahaan.

\section{KESIMPULAN}

Kesimpulan hasil pengujian dalam penelitian ini yaitu :

1. Secara parsial struktur modal berpengaruh positif dan signifikan terhadap nilai perusahaan pada perusahaan manufaktur sektor industri makanan dan minuman yang terdaftar di Bursa Efek Indonesia pada tahun 2013-2017. Hal ini ditunjukkan dari hasil perhitungan yaitu nilai t-hitung sebesar 3,087 lebih besar dari pada t-tabel sebesar 1,99 dan nilai signifikansi yang berada di bawah 0,05 yaitu sebesar 0,003

2. Secara parsial profitabilitas berpengaruh signifikan terhadap nilai perusahaan pada perusahaan manufaktur sektor industri makanan dan minuman yang terdaftar di Bursa Efek Indonesia pada tahun 20132017. Hal ini ditunjukkan dari hasil perhitungan yaitu nilai t-hitung sebesar 4,194 lebih besar dari pada t-tabel sebesar 1,99 dan nilai signifikansi yang berada di bawah 0,05 yaitu sebesar 0,000

3. Secara parsial ukuran perusahaan berpengaruh signifikan terhadap nilai perusahaan pada perusahaan manufaktur sektor industri makanan dan minuman yang terdaftar di Bursa Efek Indonesia pada tahun 2013-2017. Hal ini ditunjukkan dari hasil perhitungan yaitu nilai t-hitung sebesar 4,844 lebih besar dari pada t-tabel 
sebesar 1,99 dan nilai signifikansi yang berada di bawah 0,05 yaitu sebesar 0,000

4. Dari hasil pengujian secara simultan, menunjukkan hasil bahwa struktur modal, profitabilitas dan ukuran perusahaan secara simultan berpengaruh signifikan terhadap nilai perusahaan. Dapat dilihat dari nilai $\mathrm{F}$ hitung > F tabel yaitu $15,870>2,75$ dengan tigkat signifikansi $0,000<0,05$

\section{DAFTAR PUSTAKA}

Agus, S. 2015. Manajemen Keuangan Teori dan Aplikasi. Edisi 4. BPFE Yogyakarta

Ayu, dan Ary. 2014. Pengaruh Struktur Modal , Profitabilitas, Dan Ukuran Perusahaan Pada Nilai Perusahaan. Jurnal Akuntansi . No. $4.2: 358-372$.

Bagus, I. G., 2016. Pengaruh ukuran perusahaan dan leverage terhadap nilai perusahaan dengan profitabilitas sebagai variabel mediasi. E-Jurnal Manajemen Unud, Vol. 5 , No. 2, 1338-1367.

Bahri, S., 2016. Pengantar Akuntansi. Yogyakarta: Andi

Hanafi, M., dan Halim, A. 2015. Analisis Laporan Keuangan. Yogyakarta: (UPP) STIM YKPN

Harahap, S. 2015. Analisis Kritis atas Laporan Keuangan. Edisi 1-10. Jakarta: Rajawali Pers

Harmono. 2017. Manajemen Keuangan Berbasis Balanced Scorecard (Pendekatan Teori, Kasus, dan Riset Bisnis). Bumi Aksara, Jakarta

Hartono, J. 2016. Teori Portofolio dan Analisis Investasi. Edisi Kesepuluh, Yogyakarta

Husnan, S., dan Pudjiastuti. E., 2015. DasarDasar Manajemen Keuangan. Edisi Kelima. UPP STIM YKPN : Yogyakarta

Hery. 2016. Analisis Laporan Keuangan. PT. Gramedia Widiasarana Indonesia, Jakarta

Kasmir. 2016. Analisis Laporan Keuangan. Edisi 1. Cetakan ke-6. Jakarta: Rajawali Pers

Prastuti, Rai Kadek Ni dan I Gede Merta Sudiartha. 2016. Pengaruh Struktur
Modal, Kebijakan Deviden, dan Ukuran Perusahaan terhadap Nilai Perusahaan. E- jurnal manajemen Unud.

Sudana, I. M., (2015). Manajemen Keuangan Perusahaan. Edisi Kedu a. Jakarta : Erlangga

Sujarweni, W., 2015. Metodologi Penelitian Bisnis dan Ekonomi. Yogyakarta: Pustaka Baru Press.

Sutrisno. 2015. Manajemen Keuangan Teori, Konsep dan Aplikasi (8th ed.).Yogyakarta: Ekonisia

Sunyoto, D., 2016. Metodologi Peneitian Akuntansi. Bandung: PT Refika Aditama

Ustiani, N., 2015. Pengaruh Struktur Modal, Kepemilikan Manajerial, Keputusan Investasi, Kebijakan Dividen, Keputusan Pendanaan dan Profitabilitas Terhadap Nilai Perusahaan (Studi Pada Perusahaan Keuangan dan Perbankan Di BEI Tahun 2009-2013). ISSN: 2442-4056. Volume 1, Nomor 1, Februari 2015

Wenny, L. 2016. Analisis Pengaruh Profitabilitas, Ukuran Perusahaan, Leverage dan Pengungkapan Sosial Terhadap Nilai Perusahaan Pada Perusahaan Manufaktur Yang Terdaftar di Bursa Efek Indonesia Periode 2011 - 2015. Jurnal akuntansi, 12 (1), 29-57.

CFakultas Ekonomi Universitas Katolik Indonesia Atma Jaya 